\title{
The productivity of Maku Lotus as a forest understorey
}

\begin{abstract}
Oversowing Lotus uliginosus cv. 'Grasslands Maku' offers considerable scope for improvement of understorey forage production in New Zealand's plantation forests. In a grazing trial in Kaingaroa Forest annual forage yields of predominantly Maku lotus were $3000-5000 \mathrm{~kg} / \mathrm{ha}$ dry matter (DM) from tree age 4-7 years but declined to $1000-3000 \mathrm{~kg} \mathrm{DM} / \mathrm{ha}$ by age 11 years. Forage yields available for grazing under different tree stockings $(100,200$ and400 stems/ha) were (up to treeage 11) approximately the same, in spite of the percentage area covered with slash being significantly affected by tree stocking. Forage species composition since time of oversowing has changed from initial stands of almost pure lotus to a mixture of lotus and lower fertility grasses, particularly Yorkshire fog, and flat weeds. By tree age 11 years ( 8 years after oversowing) lotus comprises $20-30 \%$ of understorey ground cover, both with and without cattle grazing.
\end{abstract}

Keywords Maku lotus, forest understorey, forest grazing, oversowing, forage yields

\section{Introduction}

Only some 60000 ha of a total plantation forest resource of 1.2 million ha is currently grazed by livestock (Hammond 1988). Grazing of plantation forests in New Zealand has historically been of an extensive or run-off nature, often with little improvement to the economy of forest or grazier. Results indicating substantially improved growth of Pinus radiata D.Don on farm sites (West $\boldsymbol{e t}$ al. 1982; Skinner \& Attiwill 1981 a,b) suggested that introducing more intensive grazing systems with introduced legumes may provide similar benefits. Lower tree stockings (i.e., planted and final crop) and greater weed problems (particularly Cortaderia spp.) have also emphasised a more intensive and managed approach to forest grazing that may reduce forest

\author{
G.G. WEST', M.G. DEAN' and N.S. PERCIVAL' \\ 'Forest Research Institute, Rotorua \\ ${ }^{2}$ Waiariki Polytechnic, Rotorua
}

tending costs, and improve livestock and tree crop productivity (West \& Dean 1990).

An evaluation of 35 legumes in an 1 1-year-old $\boldsymbol{P}$. radiata stand in Whakarewarewa Forest (near Rotorua) indicated that Lotus uliginosus cv. Grasslands Maku' had good growth and persistence (Gadgil et al. 1986). Makulotus suits the forest grazing concept: it establishes well in soils withlow phosphorus (Morton 1980). tolerates a wide range of $\mathrm{pH}$ (Brock 1973; Lowther 1980), has a high nutritive value ( $87 \%$ of white clover) (John \& Lancashire 1981; Lowther \& Barry 1985). does not cause bloat (Jones $\boldsymbol{e t}$ al. 1970), and to date is reasonably free of insect pests and fungal pathogens.

Early oversowing studies on forest cutovers found that Maku lotus could be readily established on a range of sites (West $\boldsymbol{e t}$ al. 1988). Oversowing trials found that Maku lotus could be established in forest stands up to 4 years old if bare soil was adequate. Stands that are later thinned (at ages 10-14) have also been successfully oversown (Gadgil et al. 1988). However, due to rapid invasion of weed species, sowing should be as early as possible, generally in the same year as tree planting. Initial growth of lotus is slow andphosphate application may hasten establishment. A further development of this concept is to combine grass species with Makulotus to improve forage productivity, particularly during winter (West $\boldsymbol{e t}$ al. 1988).

A large forest grazing experiment was established in Kaingaroa Forest to evaluate the effect of oversowing Maku lotus on tree growth and pasture productivity. This paper reports understorey productivity over the first 8 years.

\section{Method}

Three tree management regimes, $1200 / 400,800 / 200$, and $400 / 100 \mathrm{stems} / \mathrm{ha}$ (tree stocking at 3 years/final stocking), were established in 1983 (referred to as the 400,200, and 100 stems/ha treatments). Tree tending operations have consisted of pruning in 3 lifts (May 1985, May 1986. November 1987) to $5.8 \mathrm{~m}$ and thinning unpruned trees at each lift. Within each regime, treatments ofovcrsowing Makulotus and grazing with 
cattle were compared with no oversowing or grazing. An additional treatment testedlotus oversowing without grazing at 200 stems/ha. Each treatment was replicated 4 times. Grazing paddocks were 0.35 ha in area with a $1.5 \mathrm{~m}$ buffer of the same tree stocking.

The site had been burnt after clearfelling of the previous crop of Pinus radiata. The tree crop was planted in winter 1980, and the site sprayed with herbicides for grass control 4months later. Oversowing was by hand-operated spinners in October 1983 applying inoculated Maku lotus seed at $5 \mathrm{~kg} / \mathrm{ha}$. Each plot was topdressed with $400 \mathrm{~kg} / \mathrm{ha}$ of molybdenised and cobaltised super-phosphate at sowing. The seedbed was mainly weed free, probably as a consequence of herbicides applied 3 years previously. Cattle were used in an attempt to trample in seed, though the effectiveness of this appeared to be poor.

Lotus establishment was best where there was some shelter, particularly near logs or other debris. Plots ( $0.35 \mathrm{ha})$ were first lightly grazed with 2-yearold bulls 6 months after oversowing, then when approximately $20 \mathrm{~cm}$ high.

Changes in botanical composition were assessed annually on 4 permanent line transects in each plot until 1987 and again in May 1991. An $8 \mathrm{~cm}$ steel ring was randomly placed at 20 points along each transect. The dominance of each species was noted using the following criteria:

value 1 is a trace, at $1-2 \%$ of area of ring; 2 , minor, 3-10\%; 3, codominant, $11-40 \%$; 4 , dominant, 41-100\%.

Measurements were made of forage yields before and after each grazing since November 1984,providing both gowth and utilisation data. The livestock grazed were 1- to 3-year-old bulls or steers from the adjacent LandCorp property - Goudies Station. Livestock numbers were allocated according to feed available, ground covered by slash (tree debris), and percentage bare ground. The grazing objective was to utilise $60 \%$ of available forage to leave a post-grazing residual of around $700 \mathrm{~kg}$ DM/ha. Forage yields were measured withacapacitanceprobeandayieldcalibrationmethod before and after each grazing (Vickery \& Nicol 1982) from November 1984. Each plot was sampled systematically with 100 capacitance readings. The number of times the probe encountered bare ground or slash was also recorded, and used to calculate percentage area covered in slash. When slash was encountered the probe was moved to an area free of slash to take a reading. This enabled calculation of total DM and, by subtracting the proportion covered with slash, the DM available for grazing.
Calibration was based on 14 samples taken across the range of the mean probe readings. Each involved taking 10 probe readings (CMRs) within a $0.12 \mathrm{~m}^{2}$ frame. The green herbage was then clipped and dried overnight in a $75^{\circ} \mathrm{C}$ oven before being weighed. A regression was fitted to describe the relationship between oven dry weights and mean probe readings. The resulting equation was then applied to paddock CMRs to calculate total DM/ha.

\section{Results}

Understorey composition

Lotus has persisted as a significant pasture component for 8 years without additional fertiliser. Percentage cover of lotus in grazed plots (Figure 1) has declined from $35-40 \%$ (theremainderbeingmainly bareground or needles) in 1985 to $20-25 \%$ in 1991 . In ungrazed oversown areas at $200 \mathrm{stems} / \mathrm{ha}$, cover by lotus has increased from 30\% of the area in 1985 (Figure 1d) to over $40 \%$ in 1991 . Tree stocking has so far had no significant effect on percentage lotus cover.

The cover of other legumes, predominantly white clover (Trifolium repens), has increased (from $0 \%$ to 6$8 \%$ in 1991) at 100 and 200 stems/ha, but is less at 400 stems/ha (2.5\% in 1991). Yorkshire fog (Holcus lanatus) has readily colonised grazed and ungrazed areas, increasing significantly at low stockings, but remaining at lower levels at $400 \mathrm{stems} / \mathrm{ha}$. Cocksfoot (Dactylis glomerata) has established at 100 stems/ha but is insignificant at higher stockings. If the more 'palatable' pasture species are grouped (lotus, other legumes, Yorkshire fog, and cocksfoot) more were found at lower stockings (viz $60 \%$ at 100 stems/ha, $50 \%$ at 200 stems/ ha, $35 \%$ at 400 stems/ha) than at higher.

Invasion by grasses (other than Yorkshire fog and cocksfoot) and flat weeds has increased at all stockings, though they comprise a minor part of the sward. Bare ground has reduced to virtually zero at all tree stockings.

Theareacoveredinneedlespeakedinalltreatments

at the second pruning in 1986. By 1991 this had declined to less than $10 \%$ in the 100 and 200 stems/ha but had remained at more than $30 \%$ in the 400 stems/ ha treatment.

\section{Slash level}

The area covered in slash (Figure 2) was $15-20 \%$ for the 3-year period (1985-88) that included the pruning and thinning operations. Since then it has dropped to 5-10\% (1988-91) andcouldbe expected tobedeclining. A clear trend with tree stocking is evident $(P=0.05)$, with slash levels increasing with tree stocking. 
Figure la. 100 stems/ha with grazing
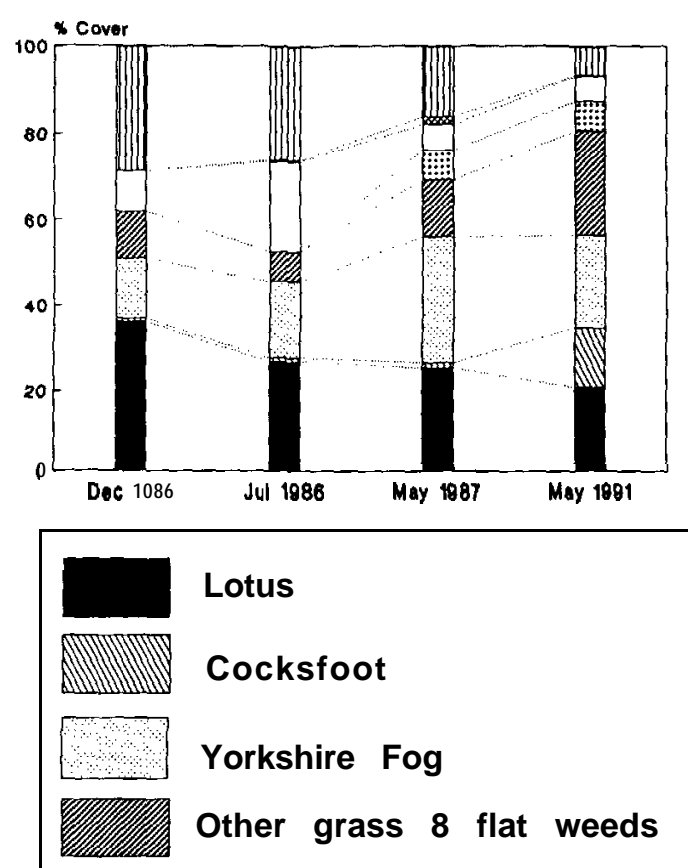

\section{Lotus}

Cocksfoot

Yorkshire Fog

Other grass 8 flat weeds
Flgure lb. 200 stems/ha with grazing

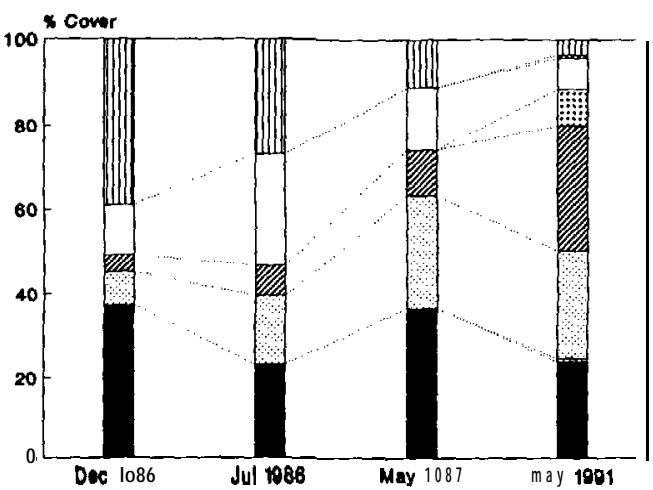

Other legumes

Tree needles

\section{Scrub}

\section{Bare ground \& Dead matter}

Figure lc. 400 stems/ha with grazing

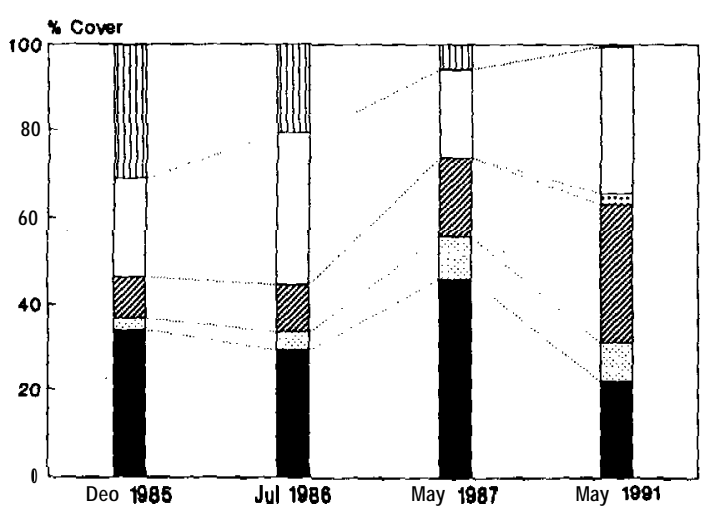

Figure Id. 200 stems/ha ungrazed

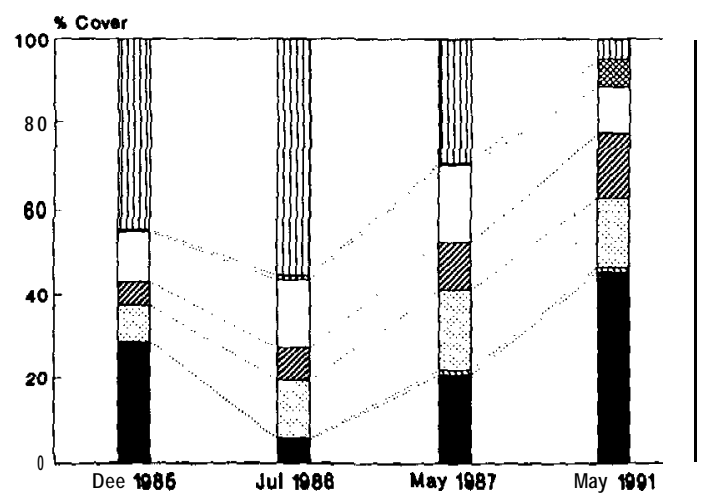

Figure 1 Understorey species development of plots in Kaingaroa forest oversown with Maku lotus.

Forage production

From the second year after sowing, rapid spring growth of lotus at this site began in early October and continued until April. Peak growth rates have occurred in Decembcr-January. Lotus production was lower in late summer during extended dry periods. From May to September lotus growth was very slow. Volunteer grasses, particularly Yorkshire fog and cocksfoot are more vigorous than lotus during this period and have provided some feed.

Over 1984-91,3-4 grazings per year have occurred, usually starting in November with a final grazing in May. There were no grazings in winter. From 1984 to 1987 (tree age 9) annual forage yields available for grazing (Figure 3) were maintained at $3000-5000 \mathrm{~kg}$ DM/ha. From 1989 through to 1991 (tree age 11) yields have declined to $1000-3000 \mathrm{~kg}$ DM/ha. Tree stocking had no significant effect on DM production. 


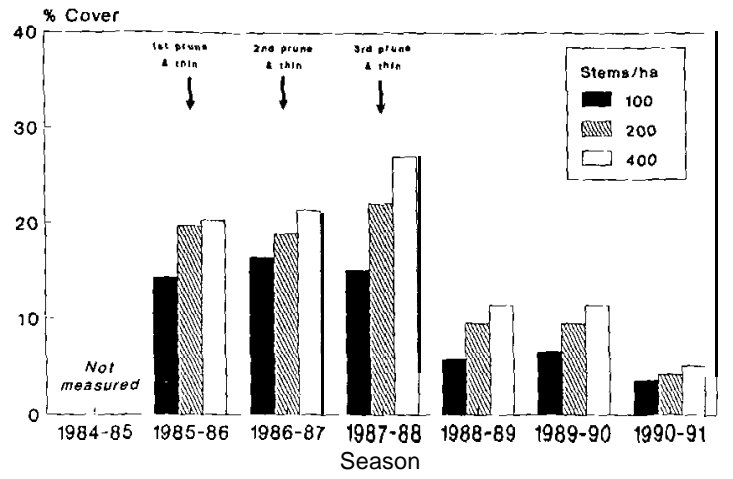

Figure 2 Annual level of slash cover for three tree stockings.

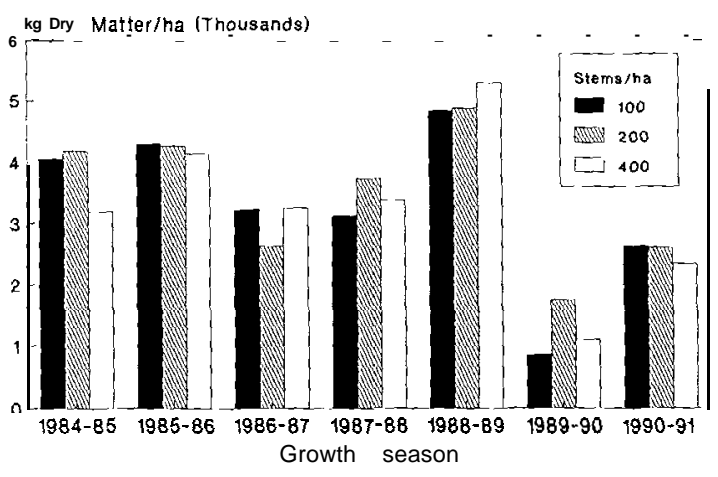

Least significant difference $(L S D)=1001 \mathrm{~kg} / \mathrm{ha}(p=0.05)$

Figure 3 Annual forage yields at Kaingaroa for three tree stockings.

\section{Discussion}

\section{Forage growth and production}

This experiment has already demonstrated the ability of Maku lotus to colonise under young $P$. radiata and persist for at least 8 years with and without cattle grazing, in spite of a low fertiliser input, viz only 400 $\mathrm{kg}$ of superphosphate/ha at sowing. Lowther (1980) also noted the persistence of Maku lotus at low levels of phosphate.

Results with Maku lotus-based swards have been similar in other North Island pine forests. Large-scale oversowing and grazing schemes have been implemented in Maramarua and Waiuku Forests near Auckland (Dale \&Todd 1988) and Kaingaroa (Goudies Grazing Scheme) near Rotorua (Brown 1988). The longevity of Maku lotus in all of these schemes, and in other small-scale sowings, is similar to that recorded in this study.

The persistence of Maku lotus under P. radiata has been greater than that with white clover in the Tikitere agroforestry experiment (Percival et al. 1984). Another striking difference between Maku lotus and white clover-based understoreys is the effect of thinning and pruning slash. Maku lotus has shown that it can recolonise slash much more quickly by way of stem growth penetrating through decaying branches and needles, and also by new plants forming from rhizomes where heavy needle fall had killed the sward. Slash from silvicultural operations has had much less effect on forage availability of lotus-based swards than on white clover-based swards.

A possible limitation of the present data is that the pastures were grazed largely around the needs of Maku lotus rather than the forage needs of a livestock system. Therefore, plots were generally not grazed between April and November, whereas in reality at least one grazing would occur during this period, as in the nearby Goudies Grazing Scheme.

The fluctuation in annual forage yields is thought to be due to the combined effects of slash build up, tree canopy reduction by pruning, and climate variation, A later analysis of these data will attempt to integrate these effects into a predictive model. The general level of Maku lotus DM production recorded in Kaingaroa fits approximately between the $8000 \mathrm{~kg} / \mathrm{ha}$ recorded by Brock (1973) without trees and the $2600 \mathrm{~kg} / \mathrm{ha}$ recorded by Gadgil et al. (1988) 1 year after sowing under lo-year-old trees.

The progressive colonisation by Yorkshire fog of the 100 and 200 stems/ha plots indicates its adaptation to these situations. It has played an increasingly important role with time in provision of some feed during autumn and winter. There is no information on whether an improved cultivar such as Massey Basyn would be an advantage over wild type Yorkshire fog. It was less successful colonising higher tree populations, such as 400 stems/ha.

\section{Wider implications}

In the past the unimproved forage quality and quantity inmost forest grazing ventures have been generally very poor. The ability of Maku lotus to grow in association with $P$. radiata thus offers not only an additional source of forage but also of a quality hitherto not possible in grazed forests. Experience with cattle grazed on Maku lotus-based swards under $P$. radiata is that substantial weight gains to a forward store condition can be readily achieved (P. Carson, pers. comm.). Other studies have shown Maku lotus to have high forage quality (John \& Lancashire 1981; Lowther \& Barry 1985).

Of at least equal importance is the introduction of a nitrogen-fixing legume to a production forest. Based on annual forage growth of $3000 \mathrm{~kg} \mathrm{DM} / \mathrm{ha}$ at $3.5 \%$ nitrogen, this will directly or indirectly return $105 \mathrm{~kg}$ $\mathrm{N} / \mathrm{ha} /$ year to the soil. Although the net gain in nitrogen 
has not been measured, lotus oversowing has significantly improved tree diameter growth and has major implications for the profitability of plantation forestry (West and Dean, in prep.).

The other major change has been the reduction in scrub weeds in grazed Maku lotus plots. This ensures there is little or no risk of ground fire in grazed forests and in some instances, where scrub-weeds would be prevalent, it substantially reduces access costs for silvicultural operations.

There are wide agricultural and forestry implications from introduction of Maku lotus to $\boldsymbol{P}$. raa'iata plantation forests. Research is presently limited to a few sites and substantial inputs are required to complete and verify the results coming from the Kaingaroa Forest experiment.

\section{ACKNOWLEDGEMENTS}

We thank the following for their contributions: Land Corp Farming Ltd, especially P. Carson; Forestry Corp. NZ Ltd; M.F. Hawke, D.I. Bond,L. Christopher, and A. Jackson of MAF; and R.L. Knowles of FRI

\section{REFERENCES}

Brock, J.L. 1973. Growth and nitrogen fixation of pure stands of three pasture legumes with high/low phosphate. NZJournal of Agricultural research 16 : 483-91.

Brown, P.C. 1988. Grazing in Kaingaroa Forest. The Goudies Project. Pp 104-1 11 in Maclaren, P. (Ed.). Proceedings of the Agroforestry Symposium, Rotorua. New Zealand, 24-27 November 1986. Ministry of Forestry, FRI Bulletin 139.

Dale, R.W.; Todd, A.C. 1988. Using cattle to control pampas grass in Maramarua and Waiuku forests. Pp 95-103 in Maclaren. P. (Ed.). Proceedings of the Agroforestry Symposium, Rotorua. New Zealand, 24-27 November 1986. Ministry of Forestry, FRI Bulletin 139.

Gadgil, R.L.; Charlton, J.F.L.; Sandberg, A.M.; Allen, P.J. 1986. Relative growth and persistence of planted legumes in a mid-rotation radiata pine plantation. Forest ecology and management 14: 113-24.

Gadgil, R.L.; Charlton, J.F.L.; Sandberg, A.M.; Allen, P.J. 1988. Establishment of selected legumes in a mid-rotation Pinus radiata plantation. NZ Journal of Forestry Science 18(2): 2 1 0-20.

Hammond, D. 1988. Survey of agroforestry in New Zealand. Pp 14-18 in Maclaren,P.(Ed.)Proceedings of the Agroforestry Symposium, Rotorua, New Zealand, 24-27November 1986. Ministry of Forestry, FRI Bulletin 139.

John, A.; Lancashire, J.A. 1981. Aspects of the feeding value of Lotus species. Proceedings of the $\mathrm{NZ}$ Grassland Association 42: 152-59.

Jones, W.T.; Lyttleton. J.W.; Clarke, R.T.J. 1970. Bloat in cattle: XXXIII. the suitable proteins of legume forages in New Zealand and their relationship to bloat. NZ Journal of Agricultural Research 13: 14956 .

Lowther, W.L. 1980: Establishment and growthofclovers and lotus on acid soils. NZ Journal of Experimental Agriculture 8: 131-8.

Lowther, W.L.; Barry, T.N. 1985. Nutritional value of lotus grown on low fertility soils. NZ Society of Animal Production 45: 125-127.

Morton,J.D. 1980: Effectoflimeandphosphateonlotus and white clover establishment and yield on pakihi soils. NZ Journal of Experimental Agriculture 8: 231-33.

Percival, N.S.; Bond, D.I.; Hawke, M.F.; Cranshaw, L.J.; Andrew, B.L.; Knowles, R.L. 1984. Effectsof radiata pine on pasture yields, botanical composition, weed populations and production of a range of grasses. Proceedings of a Technical Workshop on Agroforestry, Dunedin, May 1984. Ministry of Agriculture and Fisheries, Private Bag, Wellington.

Skinner, M.F.; Attiwill, P.M. 198la. The effects of previous land use on the productivity of pine plantations.I. Pastureeffectandroleofsoilstructure. Plant and soil 60: 161-176.

Skinner, M.F.; Attiwill, P.M. 1981b. The effects of previous land use on the productivity of pine plantations. II. Phosphorus adsorption isotherms and the growth of pine seedlings. Plant and soil 61: 329-339.

Vickey, P.J.; Nicol, G.R. 1982: An improved electronic capacitance meter for estimating pasture yield: construction details and performance tests. CSIRO Animal Research Technical paper No.9 22 p.

West, G.G.; Knowles, R.L.; Koehler, A.R. 1982: Model to predict the effects of pruning and early thinning on the growth of radiata pine. New Zealand Forest Service, FRI Bulletin No. 5.

West,G.G.; Percival,N.S; Dean,M.G. 1988:Oversowing legumes and grasses for forest grazing: interim research results. Pp. 203-20 in Maclaren, P. (Ed.) Proceedings of the Agroforestry Symposium, Rotorua, New Zealand, 24-17 November 1986. Ministry of Forestry, FRI Bulletin 139.

West, G.G.; Dean, M.G. 1990: The use of livestock to control weeds in New Zealand forests. Pp. 128-132 in Bassett, C., Whitehouse, L.J.. Zabkiewicz, J.A. (Ed.) "Alternatives to Chemical Control of Weeds". Proceedings of an International Conference, Rotorua, New Zealand, July 1989. Ministry of Forestry, FRI Bulletin 155. 